\title{
HUBUNGAN PENGETAHUAN DAN ETIKA LINGKUNGAN TERHADAP \\ PERILAKU PEDULI LINGKUNGAN MAHASISWA UNIVERSITAS KRISTEN TENTENA
}

\author{
Nurfhin Ilma Bunga \\ Fakultas Pertanian Universitas Kristen Tentena \\ E-mail : nbunga89@gmail.com
}

\begin{abstract}
ABSTRAK
Penelitian ini bertujuan untuk (1) mengetahui peran pendidikan lingkungan terhadap sikap peduli lingkungan (2) mengetahui bagaimana hubungan pengetahuan dan etika lingkungan terhadap sikap peduli lingkungan . Metode yang digunakan dalam penelitian ini adalah dengan menggunakan angket dengan beberapa pertanyaan yang berhubungan dengan pengetahuan tentang lingkungan, etika lingkungan dan sikap terhadap lingkungan. Data yang diperoleh dianalisis secara deskriptif dan analisis regresi berganda. Hasil penelitian menunjukan bahwa peran pendidikan lingkungan dapat menambah pengetahuan dan etika lingkungan sehingga meningkatkan sikap peduli mahasiswa terhadap lingkungan. Hubungan pengetahuan dan etika lingkungan terhadap sikap peduli lingkungan menunjukan hubungan yang signifikan dengan nilai $r=0,563$; nilai konstanta $=1,383$; nilai koefisien pengetahuan lingkungan hidup 0,899; koefisien etika lingkungan 0,995; sehingga diperoleh persamaan regresi $Y 1=0,899 X 1+0,995 X 2+1,383$ dan signifikansi 0,000. Untuk meningkatkan sikap peduli mahasiswa terhadap lingkungan disarankan agar pihak lembaga mengembangkan pendidikan lingkungan dengan metode-metode pembelajaran yang aplikatif.
\end{abstract}

Kata kunci : Pendidikan Lingkungan, Etika Lingakungan, Sikap Peduli Terhadap Lingkungan 


\section{PENDAHULUAN}

Perubahan lingkungan yang terjadi akhir-akhir ini menjadi suatu kejadian yang menyentak pikiran kita. Beberapa fenomena yang terjadi akibat menurunnya kualitas lingkungan, tidak lepas dari perilaku dan ketidakpedulian manusia terhadap lingkungan. Seiring dengan bertambahnya jumlah penduduk, kebutuhan dan meningkatnya ilmu pengetahuan dan teknologi menyebabkan manusia melakukan eksploitasi tehadap lingkungan. Namun, tidak berhenti hanya disitu saja, ketidakpuasan manusia yang ingin mendapatkan keuntungan yang sebesar-besarnya, maka tanpa memperhatikan fungsi dan akibat, manusia mengeksploitasi lingkungan secara berlebihan.

Permasalahan tersebut diatas menyebabkan kita berpikir apakah pendidikan lingkungan yang selama ini diterapkan apakah kurang optimum, apakah kepedulian masyarakat terhadap lingkungan sedang mengalami krisis? Untuk mengatasi masalah tersebut, maka diharapkan pendidikan lingkungan yang telah diterapkan mampu memberi pemahaman, dan perilaku yang peduli terhadap lingkungan. Setyowati, dkk, 2014 mengemukakan bahwa pendidikan lingkungan hidup diperlukan untuk dapat mengelola secara bijaksana sumber daya kita dan menumbuhkan rasa tanggung jawab terhadap kepentingan generasi yang akan datang, diperlukan pengetahuan, sikap dan ketrampilan atau perilaku yang membuat sumber daya kita tetap dapat dimanfaatkan secara lestari atau dapat dimanfaatkan secara berkelanjutan. Upaya dari pemerintah pun telah dilakukan dengan dikeluarkannya UURI No. 4 Tahun 1982 kemudian diperbaiki dengan UURI No.23 Th 1997. Selanjutnya Depdiknas telah memasukkan pendidikan lingkungan ini, baik terintegrasi dengan mata pelajaran lain maupun dalam muatan lokal. Pembukaan konferensi Stockholm pada tanggal 5 Juni diperingati sebagai hari lingkungan hidup. Perkembangan selanjutnya PLH pada tahun 1996 ditetapkan Memorandum Bersama antara Departemen Pendidikan dan Kebudayaan dengan Kantor Menteri Negara Lingkungan Hidup No. 0142/U/1996 dan No Kep: 89/MENLH/5/1996 tentang Pembinaan dan Pengembangan Pendidikan Lingkungan Hidup, tanggal 21 Mei 1996.

Mengingat pendidikan lingkungan sangat penting, dan diharapkan dapat meminimalisir berkembangnya agen perusak lingkungan. Universitas Kristen Tentena telah memasukan mata kuliah Pengantar Kajian Lingkungan Hidup (PKLH) sebagai salah satu mata kuliah wajib. PKLH merupakan pemberian pemahaman mengenasi sikap dan perilaku peduli terhadap lingkungan. Dengan adanya mata kuliah PKLH yang diterapkan di Universitas Kristen Tentena maka diharapkan terbentuknya manusia berpendidikan yang 
peduli terhadap lingkungan. Berdasarkan hal tersebut, peneliti ingin mengetahui pengaruh pengetahuan dan etika lingkungan dalam membentuk perilaku peduli terhadap lingkungan.

\section{METODE PENELITIAN}

\section{Waktu dan Tempat Penelitian}

Penelitian ini dilaksanakan di lingkungan Universitas Kristen Tentena selama empat bulan yakni pada bulan Januari - April 2014

\section{Populasi dan Sampel}

Populasi penelitian ini adalah seluruh mahasiswa semester dua pada fakultas yang memiliki mata kuliah PKLH. Berdasarkan data dari bagian akademik jumlah mahasiswa semester empat sebanyak 163 mahasiswa dan jumlah yang sama untuk mahasiswa semester dua tahun ajaran 2016/2017 genap yaitu 163 mahasiswa. Untuk pengambilan sampel dilakukan dengan menggunakan teknik Propotrtionate randon sampling sampel diklasifikasikan menurut fakultas sebanyak 15\%. Sehingga jumlah sampel yang diperoleh yakni sebanyak 22 mahasiswa yang telah mengikuti perkuliahan mata kuliah PKLH dan 22 mahasiswa yang belum mengikuti perkulihan PKLH.

\section{Teknik Pengumpulan Data}

Teknik pengumpulan data menggunakan kuesioner/angket skala likert. Yaitu dengan mengajukan beberapa pertanyaan yang berhubungan dengan perilaku dan sikap mahasiswa setelah mengikuti perkuliahan PKLH.

\section{Analisis Data}

Analisis data yang digunakan adalah analisis regresi linear berganda. Variabel pengetahuan dan etika lingkungan sebagai variabel bebas dan variabel perilaku/tindakan peduli lingkungan sebagai variabel terikat.

\section{Hasil dan Pembahasan}

Distribusi Mahasiswa Menurut Variabel Pengetahuan, Etika Lingkungan dan Perilaku

\section{Peduli Lingkungan}

Ada beberapa pertanyaan diajukan mengenai pengetahuan tentang lingkungan. Antara lain pemahaman tentang lingkungan itu sendiri. Dari 26 orang mahasiswa yang telah mengikuti perkuliahan PKLH, sebanyak 18 atau 81,8 \% mahasiswa menjawab dengan tepat, yakni segala sesuatu yang ada disekitar kita yang mempengaruhi sikap dan perilaku manusia dan sisanya menjawab bahwa lingkungan itu adalah tanah, air dan udara saja. Hal ini menunjukan bahwa hampir sebagian besar mahasiswa telah memahami arti dari lingkungan hidup. Dan pertanyaan lain seperti fungsi lingkungan, mengapa lingkungan perlu dijaga kelestariannya, apa unsur-unsur lingkungan, apa saja yang menjadi masalah lingkungan, apa 
yang menjadi penyebab dan dampak dari kerusakan lingkungan dan bagaimana cara mengendalikan kerusakan lingkungan. Berturut-turut jumlah mahasiswa yang menjawab dengan tepat untuk pertanyaan ke dua hingga ke tujuh yaitu 21 mahasiswa (95,5\%), 15 mahasiswa (68,2\%), 13 mahasiswa (59,1\%), 17 mahasiswa (77,3\%), 20 mahasiswa (90,9\%), 19 mahasiswa $(86,4 \%)$ dan sisanya menjawab belum tepat.

Jika dibandingkan dengan mahasiswa yang belum mengikuti perkuliahan mata kuliah Pengantar Kajian Lingkungan Hidup (PKLH) ketepatan menjawab setiap pertanyaan lebih banyak didominasi atau dijawab dengan tepat oleh mahasiswa yang telah mengikuti perkuliahan PKLH. Sedangkan mahasiswa yang belum mengikuti perkuliahan PKLH, jumlah mahasiswa yang menjawab dengan tepat pertanyaan pertama hingga pertanyaan ketujuh yaitu 8 mahasiswa (36,4\%), 8 mahasiswa (36,4\%), 6 mahasiswa (27,3\%), 6 mahasiswa $(27,3 \%), 4$ mahasiswa (18,2\%), 7 mahasiswa (31,8\%), 12 mahasiswa (54,5\%). Berdasarkan hal tersebut, dapat dilihat bahwa adanya pendidikan lingkungan yang diterapkan dapat menambah khasanah pengetahuan mahasiswa mengenai lingkungan. Perbadingan respon dari setiap pertanyaan yang diajukan terhadap responden dapat dilihat pada gambar 1 .

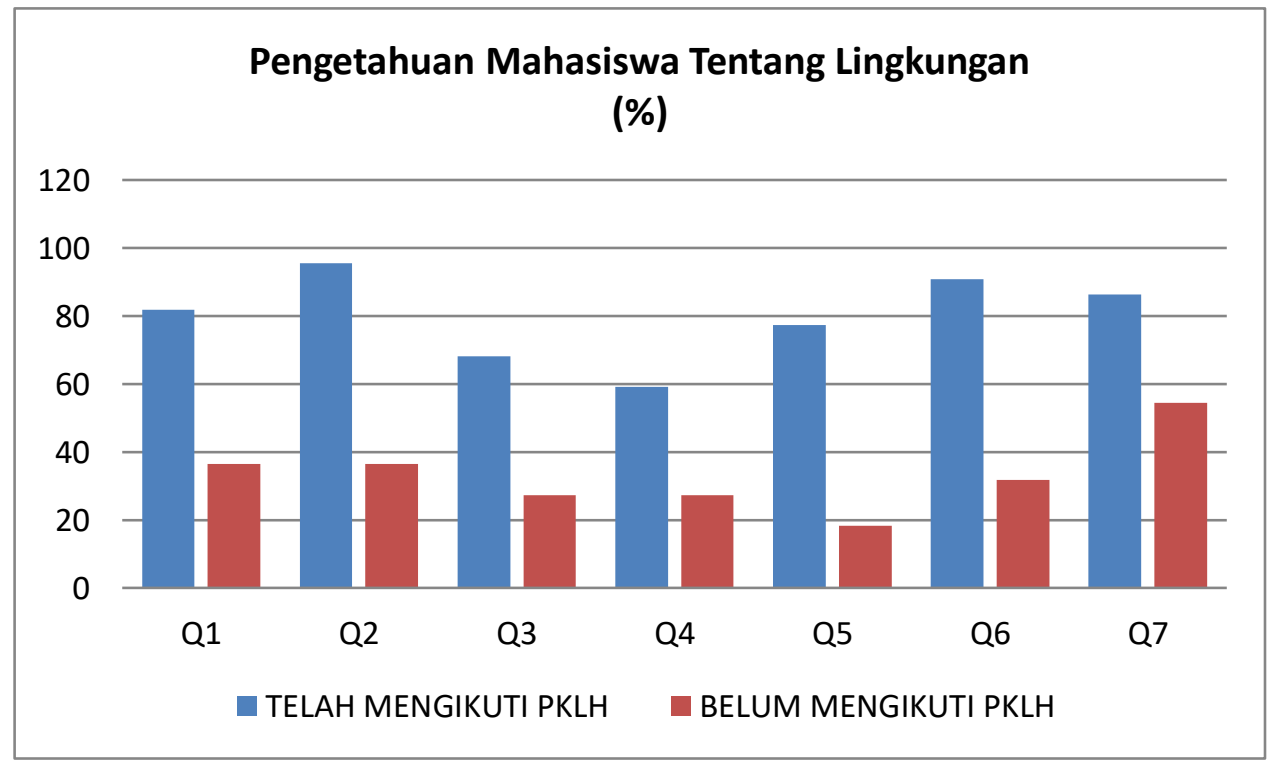

Gambar 1. Pengetahuan Mahasiswa UNKRIT Tentang Lingkungan

Untuk etika atau kebiasaan yang dilakukan dalam upaya menjaga dan melestarikan lingkungan, seperti kebiasaan membuang sampah pada tempatnya, membawa kantong belanja sendiri ketika berbelanja, tidak menggunakan kantong plastik dan mendaur ulang barang-barang yang tidak terpakai. Dari beberapa pertanyaan tersebut, mahasiswa yang telah mengikuti perkuliahan PKLH sebanyak 14 orang atau 63,6 \% menjawab cukup sering membuang sampah pada tempatnya sedangkan sisanya menjawab kadang-kadang saja membuang sampah pada tempatnya. Menggunakan kantong belanja sendiri saat berbelanja 
hanya dilakukan sebanyak 11 mahasiswa atau 50\%, sisanya sebanyak 50\% hanya kadangkadang atau tidak sama sekali mengguanakan kantong belanja sendiri. Dengan alasan, lebih praktis dan lebih mudah menggunakan kantong plastik yang telah disediakan oleh penjual, daripada harus membawa sendiri kantong belanja. Begitu pula yang melakukan proses daur ulang barang-barang yang tidak terpakai, hanya dilakukan oleh 11 orang atau 50\%. Untuk mahasiswa yang belum mengikuti perkuliahan, sebanyak 13 mahasiswa $(59,1 \%)$ yang masih membuang sampah sembarangan, 16 mahasiswa (72,7\%) menggunakan kantong plastik yang disediakan oleh penjual. Dan yang telah melakukan daur ulang barang-barang yang tidak terpakai adalah 13,6 \% saja, sisanya sebanyak 86,4 \% tidak melakukan daur ulang, barangbarang tersebut hanya disimpan saja digudang atau dibuang (Gambar 2).

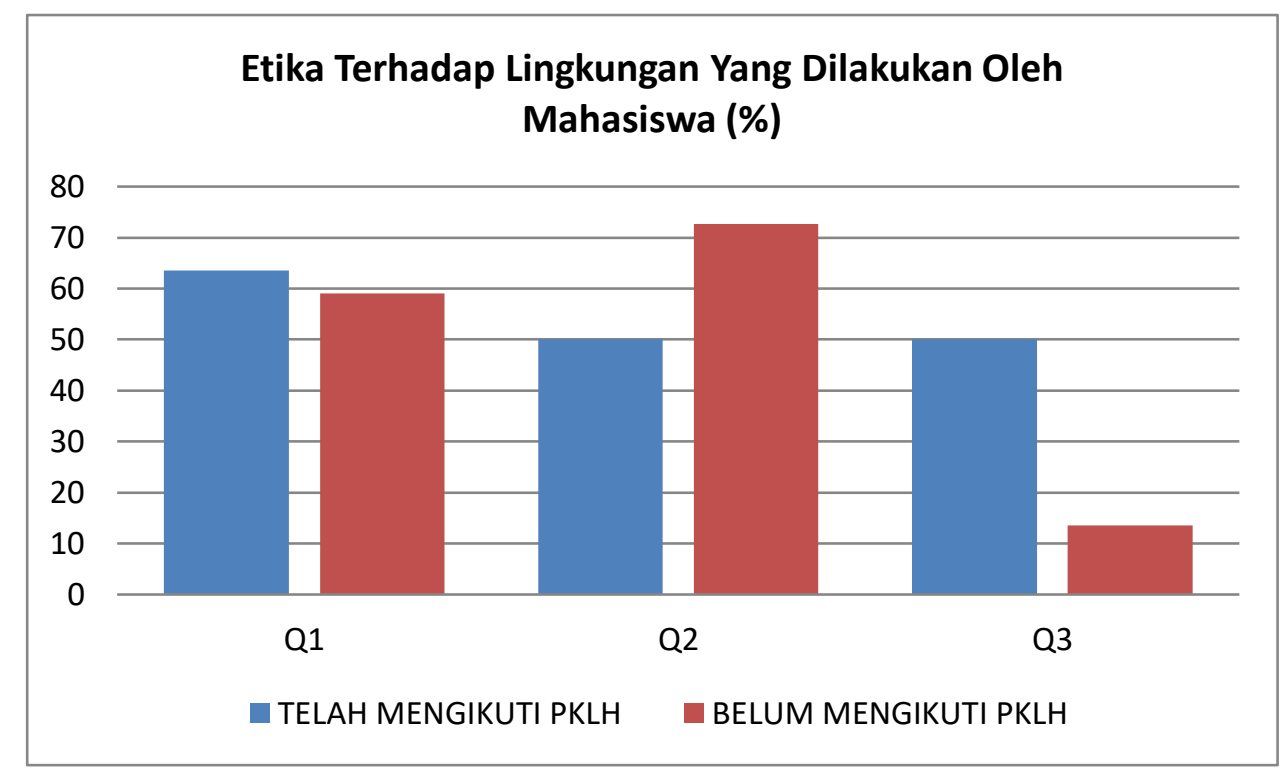

Gambar 2. Etika Terhadap Lingkungan Yang Dilakukan Oleh Mahasiswa

Selain variabel pengetahuan dan etika lingkungan, untuk mengetahui persepsi mahasiswa tentang pengelolaan lingkungan diajukan pula beberapa pernyataan mengenai sikap dan perilaku peduli terhadap lingkungan. Pernyataan tersebut antara lain, akibat dari pencemaran lingkungan hanya dirasakan oleh masyarakat tertentu saja. Pernyataan ini mendapat respon dari mahasiswa yang telah mengikuti perkuliahan PKLH sebanyak 17 mahasiswa atau $77,3 \%$ bahwa pencemaran lingkungan tidak hanya dirasakan oleh masyarakat tertentu saja tetapi oleh semua elemen masyarakat. Sedangkan sisanya menyatakan bahwa pencemaran lingkungan hanya dirasakan oleh masyarakat tertentu saja dengan beberapa opini antara lain masyarakat yang rajin dan selalu melestarikan lingkungan akan terhindar dari dampak pencemaran lingkungan seperti penyakit. Membuang sampah didanau, menurut 21 mahasiswa $(95,5 \%)$ bahwa aktivitas tersebut memberikan dampak yang berarti, antara lain merusak ekosistem danau, mencemari air danau dan dapat menjadi sumber atau sarang 
penyakit. Lingkungan dijaga hanya berdasarkan kebutuhan saja, seluruh mahasiswa 22 mahasiswa atau (100\%) menyikapi bahwa lingkungan dijaga bukan hanya untuk sekedar kebutuhan saja, tetapi juga untuk kebutuhan secara global dan berkelanjutan. Mengikuti perkuliahan PKLH, menurut 86,4 \% mahasiswa tidak hanya untuk memenuhi syarat perkuliahan saja tetapi dapat memberi pengetahuan dan kesadaran untuk terus aktif melestarikan lingkungan.

Berdasarkan Gambar 3. mengenai persepsi dari mahasiswa yang belum mengikuti perkuliahan PKLH menyikapi pernyataan-pernyataan tersebut, dapat dilihat bahwa sebanyak 45\% mahasiswa menyatakan bahwa pencemaran lingkungan tidak hanya dirasakan masyarakat tertentu saja. Hanya $37 \%$ mahasiswa yang berpendapat bahwa membuang sampah di danau memberikan dampak yang berarti. Sebanyak $20 \%$ mahasiswa yang setuju bahwa lingkungan dijaga tidak hanya berdasarkan kebutuhan saja. Dan sebanyak 29\% mahasiswa yang berpendapat bahwa mata kuliah PKLH dapat memberikan pengetahuan dan kesadaran untuk terus aktif melakukan lingkungan.

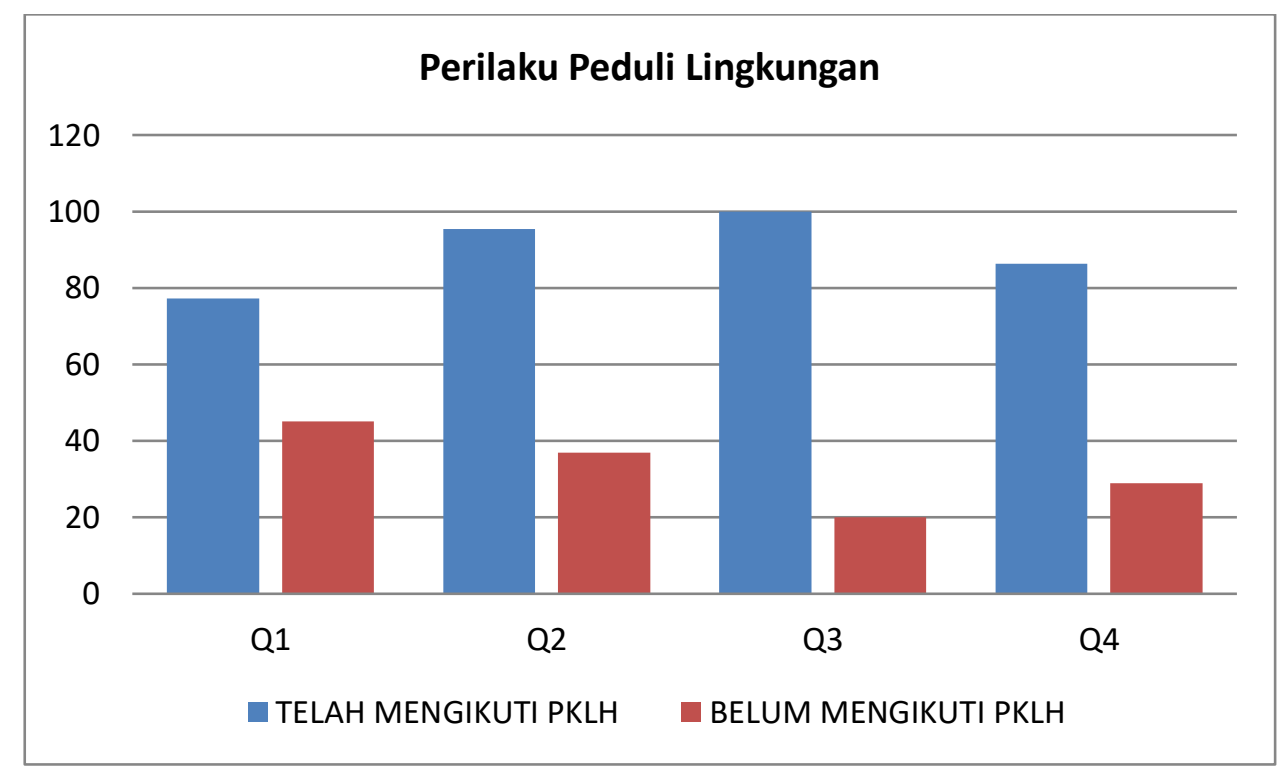

Gambar 3. Perilaku Peduli Lingkungan Mahasiswa UNKRIT

\section{Hubungan Pengetahuan dan Etika Lingkungan Terhadap Perilaku Peduli Lingkungan}

Hasil analisis regresi berganda didapatkan hasil $\mathrm{r}=0,563$; nilai konstanta $=1,383$; nilai koefisien pengetahuan lingkungan hidup 0,899; koefisien etika lingkungan 0,995; persamaan regresinya $\mathrm{Y} 1=0,899 \mathrm{X}_{1}+0,995 \mathrm{X}_{2}+1,383$ dan signifikansi 0,000 .

Berdasarkan hasil analisis hubungan pengetahuan dan etika lingkungan dengan sikap atau perilaku menjaga lingkungan diperoleh nilai sig. $0,000<0,005$ dan $\mathrm{r}=0,750$ ini menunjukan bahwa terdapat hubungan positif yang signifikan. Apabila nilai pengetahuan dan etika lingkungan mengalami kenaikan,maka nilai sikap atau perilaku menjaga lingkungan 
juga akan meningkat. Sebaliknya jika nilai pengetahuan dan etika lingkungan mengalami penurunan, maka nilai sikap atau perilaku menjaga lingkungan juga akan ikut menurun.

Peningkatan nilai sikap yang dipengaruhi oleh pengetahuan dan etika lingkungan mahasiswa di Universitas Kristen Tentena dapat disimulasikan sebagai berikut :

a. Apabila nilai pengetahuan dan etika lingkungan mahasiswa sama dengan nol, maka besarnya nilai sikap atau perilaku menjaga lingkungan adalah konstan yaitu 1,383.

b. Apabila nilai pengetahuan tentang lingkungan meningkat satu poin dan pengetahuan etika lingkungan diasumsikan nol, maka sikap atau perilaku menjaga lingkungan mahasiswa Universitas Kristen Tentena meningkat menjadi 2,282.

c. Apabila nilai etika lingkungan meningkat satu poin dan nilai pengetahuan tentang lingkungan diasumsikan nol, maka sikap atau perilaku menjaga lingkungan mahasiswa Universitas Kristen Tentena meningkat menjadi 2,378

d. Apabila nilai pengetahuan tentang lingkungan hidup dan pengetahuan etika lingkungan juga meningkat satu poin, maka nilai sikap atau perilaku akan meningkat mahasiswa Universitas Kristen Tentena meningkat cukup signifikan sebesar 3,277.

Berdasarkan simulasi tersebut dapat dilihat bahwa semakin meningkatnya pengetahuan dan etika lingkungan mahasiswa, maka sikap peduli terhadap lingkungan akan semakin terbentuk, hal tersebut sependapat dengan Azwar (2011) yang mengungkapkan bahwa pembentukan sikap dipengaruhi oleh beberapa faktor yakni pengalaman pribadi, kebudayaan, orang lain yang dianggap penting, media massa, lembaga pendidikan, dan lembaga agama, dan factor emosional. Sehingga pendidikan tentang lingkungan hidup sangat penting dalam membentuk sikap mahasiswa peduli terhadap lingkungan. Hal tersebut juga sependapat dengan Kaiser, dkk (1999) yang mengemukakan bahwa informasi atau pengetahuan factual adalah syarat penting bagi sikap.

Etika merupakan suatu adat istiadat atau kebiasaan yang dianggap baik (Keraf,2006). Sehingga dengan adanya etika terhadap lingkungan yang didapatkan oleh mahasiswa dari lingkungannya baik keluarga, lembaga dan lingkungan social lainnya dapat membentuk sikap dan perilaku peduli terhadap lingkungan dan hal ini sependapat dengan Djaelani, M. S.,(2011) yang menyatakan bahwa kualitas lingkungan dipengaruhi oleh etika lingkungan yang dimiliki oleh masing-masing individu. 


\section{Kesimpulan dan Saran}

Berdasarkan hasil penelitian dapat diambil kesimpulan sebagai berikut :

a. Pendidikan lingkungan dapat membentuk sikap perilaku peduli terhadap lingkungan yang terlihat dari perbandingan distribusi frekuensi mahasiswa yang telah mengikuti perkuliahan PKLH dan mahasiswa yang belum mengikuti perkuliahan PKLH. Mahasiswa yang telah mengikuti perkuliahan PKLH cenderung memiliki banyak pengetahuan tentang lingkungan dan memahami etika terhadap lingkungan, sehingga membentuk sikap yang peduli lingkungan.

b. Pengetahuan tentang lingkungan dan etika lingkungan berdasarkan hasil analisis memiliki hubungan yang signifikan.

Dalam meningkatkan sikap peduli lingkungan mahasiswa disarankan :

a. Universitas terus membina dan mengembangkan pendidikan lingkungan ditingkat mahasiswa.

b. Pendidikan lingkungan diharapkan menggunakan metode-metode pembelajaran yang lebih aplikatif.

c. Sebaiknya pendidikan lingkungan tidak hanya diajarkan di tingkat universitas saja, tetapi diseluruh elemen pendidikan. Karena dengan adanya pendidikan lingkungan sejak dini dapat membentuk generasi cerdas yang peduli terhadap lingkungan hidup.

d. Perlu dilakukan penelitian lanjutan sehubungan pendidikan lingkungan ditingkat pelajar dari Taman Kanak-Kanak hingga Sekolah Menengah Atas dan bahkan ke tingkat masyarakat.

\section{Daftar Pustaka}

Azwar, S. 2011. Sikap Manusia: Teori dan Pengukurannya Edisi ke-2. Pustaka Pelajar Yogyakarta.

Djaelan, M.S.,2011. Etika Lingkungan Dalam Pembangunan Berkelanjutan. Jurnal Econo Sains. Vol IX. No. 1

Keraf, S. A.,2006. Etika Lingkungan. Jakarta: Kompas

Kaiser, F.G., dan Fuhrer, U., 2003. Ecological Behaviour's Dependency on Different Forms of Knowledge. Applied Psychology. 52:598-613.

Wardhana, W. A. 2004. Dampak Pencemaran Lingkungan. Penerbit Andi, Yogyakarta. 